NBER WORKING PAPER SERIES

\title{
REGULATING ADVERTISEMENTS: THE CASE OF SMOKING CESSATION PRODUCTS
}

\author{
Rosemary J. Avery \\ Donald S. Kenkel \\ Dean R. Lillard \\ Alan D. Mathios \\ Working Paper 12001 \\ http://www.nber.org/papers/w12001
NATIONAL BUREAU OF ECONOMIC RESEARCH
1050 Massachusetts Avenue
Cambridge, MA 02138
January 2006

This research was supported by Award \# R01 CA094020-01 from the National Cancer Institute, and an unrestricted educational grant from The Merck Company Foundation, the philanthropic arm of Merck \& Co. Inc. Andrew Sfekas provided excellent research assistance. We thank participants at various seminars and conferences for helpful comments; the usual disclaimers apply. The views expressed herein are those of the author(s) and do not necessarily reflect the views of the National Bureau of Economic Research.

(C)2006 by Rosemary J. Avery, Donald S. Kenkel, Dean R. Lillard, and Alan D. Mathios. All rights reserved. Short sections of text, not to exceed two paragraphs, may be quoted without explicit permission provided that full credit, including (C) notice, is given to the source. 
Regulating Advertisements: The Case of Smoking Cessation Products

Rosemary J. Avery, Donald S. Kenkel, Dean R. Lillard, and Alan D. Mathios

NBER Working Paper No. 12001

January 2006

JEL No. I1, L5

\section{ABSTRACT}

In this paper we investigate how direct-to-consumer (DTC) advertising of pharmaceutical products in affected by regulations of the Food and Drug Administration and by market conditions. We focus on a relatively under-studied segment of the pharmaceutical market -- the market for smoking cessation products. Because of their proven effectiveness, these products could be the key to meeting public health goals to reduce smoking. However, in many ways, smoking cessation products have been more heavily regulated than cigarettes. Our empirical analysis uses data on advertising expenditures and data from an archive of print advertisements. The archive includes all smoking cessation product advertisements that appeared in over 13,000 issues of 28 magazines between January 1985 and May 2002. Our study period begins shortly atfer the first nicotine replacement product was introduced, and covers the evolution of the market as new products are introduced while some of the older products move from prescription to over-the-counter (OTC) status. OTC status eases the disclosure requirements imposed on advertisements of prescription pharmaceuticals, substantially reducing the costs of a print advertisement. Our results suggest that OTC status is associated with an increase in advertising expenditures and the number and pages of magazine advertisements. A current proposal to reduce disclosure requirements on all DTC advertisements of prescription drugs could have similar effects. Our results also suggest that advertising increase with the introduction of new products and with market competition.

Rosemary J. Avery

Department of Policy Analysis and Management

MVR Hall

Cornell University

Ithaca, NY 14850

rja7@cornell.edu

Donald S. Kenkel

Department of Policy Analysis and Management

MVR Hall

Cornell University

Ithaca, NY 14850

and NBER

dsk10@cornell.edu
Dean R. Lillard

Department of Policy Analysis and Management

MVR Hall

Cornell University

Ithaca, NY 14850

dr13@cornell.edu

Alan D. Mathios

Department of Policy Analysis and Management

MVR Hall

Cornell University

Ithaca, NY 14850

adm5@cornell.edu 


\section{Introduction}

Cigarette industry advertisements and anti-smoking public service campaigns are familiar features of the U.S. mass media. A large body of economics research investigates cigarette advertising and the impact of regulating or even banning cigarette advertisements. ${ }^{1}$ A similarly large body of public health research addresses the design and impact of public service antismoking campaigns. ${ }^{2}$ The 1998 Master Settlement Agreement between states and the tobacco industry simultaneously imposed new restrictions on cigarette advertising and established new anti-smoking media campaigns (Bulow and Klemper 1998, Gruber 2001). In contrast to the intense focus on other smoking-related advertisements, researchers almost seem to have overlooked advertisements of pharmaceutical products for smoking cessation. ${ }^{3}$ In this paper, we empirically investigate firms’ decisions to advertise as the new market for smoking cessation products developed. We focus particularly on how Food and Drug Administration (FDA) regulations affect these advertising decisions.

${ }^{1}$ For a meta-analysis, Gallet and List (2003) identify 137 estimates of the elasticity of cigarette demand with respect to advertising expenditures. Chaloupka and Warner (2000) review 13 econometric studies that examine the impact of the U.S. ban on broadcast cigarette advertising, while a smaller research literature uses pooled international data sets to study the impact of cigarette advertising bans (Saffer and Chaloupka 2000, Nelson 2003).

${ }^{2}$ Chapters 3 and 7 of the 2000 Surgeon General's Report review evidence on the effectiveness of counter-advertising campaigns (USDHHS 2000a). Several econometric studies compare the impact of industry advertising versus public service counter-advertisements by exploiting the fact that the U.S. ban on television advertising also resulted in the elimination of anti-smoking counter-advertisements required by the Fairness Doctrine (Lewit, Coate and Grossman 1981, Schneider, Klein and Murphy 1981).

${ }^{3} \mathrm{Hu}$ et al. (2000) and Keeler et al. (2002) study the aggregate sales of smoking cessation products, while Tauras and Chaloupka (2003) use scanner data to estimate consumer demand for smoking cessation products. However, none of these studies focuses on advertising in this market. 
Our study of smoking cessation product advertisements contributes to research on another increasingly familiar feature of U.S. mass media - direct-to-consumer (DTC) advertisements of pharmaceuticals. The debate on whether DTC advertising leads to better or worse consumer health care often involves analysis of the regulatory system as a whole (Mintzes 2001, 2002, Calfee 2002). However, the benefits and costs of regulating DTC advertisements are likely to vary greatly, depending on the medical condition the drug treats and the knowledge base of consumers. To improve understanding of the benefits and costs in specific contexts, recent empirical studies focus on the impact of DTC advertising on the demand for narrow classes of pharmaceutical products (Berndt et al. 1995, Iizuka and Jin 2002, Ling, Berndt and Kyle 2002, Calfee, Winson and Stempski 2003, Rosenthal et al. 2003, and Wosinska 2002, 2003). Rather than analyzing the role of DTC advertising regulations on all pharmaceuticals broadly, or estimating the impact of DTC advertising on consumer demand, in this paper we examine the impact of FDA regulations on firms' advertising choices in a specific market. In the market we look at - the market for pharmaceutical products approved as aids for smoking cessation - DTC advertising plays a particularly important role: Ma et al. (2003) find that in 1998 smoking cessation was the only class of drugs primarily advertised directly to consumers, rather than to physicians or to both consumers and physicians.

The market for smoking cessation products is potentially very important for public health. A public health initiative, Healthy People 2010, aims to cut the prevalence of smoking among adults in half, from the current rate of about 24 percent to 12 percent (USDHSS 2000b). Over the past twenty years, the pharmaceutical industry has introduced a number of products designed to help smokers quit. Because of their proven effectiveness, these products could be 
the key to meeting the Healthy People 2010 goal. For example, Hays et al. (1999) report that nicotine patch therapy generally doubles abstinence rates over placebo controls in both shortand long-run follow-ups. While recent policy debates have tended to focus on how to prevent youth from starting to smoke, a recent analysis concludes that the Healthy People 2010 goal cannot be met without large increases in smoking cessation rates (Mendez and Warner 2000, 2004).

Despite the potential public health significance of smoking cessation products, current regulatory policy towards consumer information about smoking seems disjointed. FDA regulation of prescription drugs results in a peculiar regulatory asymmetry: in many ways, smoking cessation products have been much more heavily regulated than cigarettes. For example, to comply with FDA regulations the typical DTC advertisement of a prescription drug for smoking cessation includes a full extra page disclosing information on side effects, contraindications, and effectiveness. In contrast, a cigarette advertisement only needs to include a relatively small warning label. The irony is that smoking cessation product advertisements may serve some of the same public health goals as public service anti-smoking campaigns. For example, in 1996 the Great American Smokeout, sponsored by the American Cancer Society, included activities in collaboration with a manufacturer of nicotine medications (Burton et al. 1997) . More generally, previous research suggests that producers’ health claims in advertisements are important sources of consumer information about a range of topics, including dietary fiber in breakfast cereals (Ippolito and Mathios 1990, 1991), the fat content of foods (Ippolito and Mathios 1995, Mathios 1998, 2000), and aspirin and heart attacks (Keith 1995). We contribute to this line of research by describing and analyzing the flow of producer-provided 
information about smoking cessation.

The rest of the paper proceeds as follows. In section II we provide a brief history of the market for smoking cessation products and its regulatory environment. In section III, we describe the data we use. Our two primary sources of data are: (i) advertising expenditures by media type; and (ii) an archive of DTC print advertisements. The archive includes all smoking cessation product advertisements that appeared in over 13,000 issues of 28 magazines between January 1985 and May 2002. Our study period begins shortly after the first nicotine replacement product was introduced, and covers the evolution of the market as new products are introduced while some of the older products move from prescription to over-the-counter status. Section IV describes the econometric model and hypotheses to be tested and Section V presents our results. In the final section we summarize our results and discuss the implications for public policy and future research.

\section{Evolution of the Market for Smoking Cessation and the Regulatory Environment The Market for Smoking Cessation}

Since the first Surgeon General's Report on the hazards of smoking was published in 1964, the prevalence of smoking among U.S. adults has dropped from 42 percent to about 24 percent. To give an idea of the importance of the role of smoking cessation in this drop, currently there are about as many former smokers (23 percent of adults) as there are current smokers. Put differently, the number of former smokers as a fraction of lifetime (current and former) smokers, sometimes called the quit ratio, is now almost 50 percent, up from 30 percent in 1965 (USDHHS 1989, 2000, Schoenborn, Vickerie, and Barnes 2003).

Interest in tobacco cessation has been long-standing; an advertisement for a "tobacco 
cure” appeared in Harper's Weekly in 1862 (HarpWeek 2004). However, only recently have pharmaceutical innovations led to smoking cessation methods of proven effectiveness. A review of research published between 1957 to 1968 concludes that "few [methods] have shown high success rates.” (Schwartz 1969). Reviews of research published between 1969-1977 (Schwartz and Rider 1977) and 1978-1985 (Schwartz 1987) identify some promising non-pharmacological methods; but they also note deficiencies in the research design and methods that cast doubt on the findings for methods such as hypnosis and acupuncture. ${ }^{4}$ In contrast, based on a metaanalysis of evidence from clinical trials, the current Public Health Service's Clinical Practice Guidelines concludes that "Numerous effective pharmacotherapies for smoking cessation now exist....that reliably increase long-term smoking abstinence rates,” and identifies buproprion, nicotine gum, nicotine inhaler, nicotine nasal spray, and the nicotine patch as first-line pharmacotherapies (USDHHS 2000c). The result of the meta-analysis suggest that smokers randomly assigned to use the pharmaceutical products are 1.5 to 3 times more likely to successfully quit than smokers in the placebo control groups.

Table 1 documents the rapid developments in the market for pharmaceutical smoking cessation products and its regulatory environment. For now we will focus mainly on the history of the product market; the regulatory history is discussed in more detail below. From its introduction in 1984 until 1991 nicotine gum was the only pharmaceutical product approved for use as an aid to smoking cessation. Over the 1990s, pharmaceutical companies competed in this

\footnotetext{
${ }^{4}$ Schwartz (1987, p. 47) concludes that "It is difficult to assess the true effect of hypnosis as a treatment for smoking since the studies reported were weak in followup methodology ;”and that "The comments regarding the methodology and evaluation of hypnosis trials...apply as well to acupuncture.” (p. 50).
} 
market by introducing nicotine patches, nasal spray, and inhalers. In addition, in 1997 the antidepressant buproprion was approved for smoking cessation under the name Zyban. Varenicline, a nicotine agonist, is currently in phase III clinical trials. Other recent developments include new flavors of nicotine gum, a nicotine lozenge, and emerging competition from generic versions of nicotine gum and patch marketed at retail establishments like Wal-Mart.

The development of effective pharmaceutical aids for smoking cessation is changing the way many smokers quit, and may be increasing smoking cessation rates. As recently as 1987, almost 90 percent of former smokers had quit 'cold turkey,' and only 1.5 percent had used nicotine gum, the only nicotine replacement therapy available (USDHSS 1989). Currently, about twenty percent of smokers use a pharmaceutical product when they try to quit (Plassman et al. 2005). Two recent econometric studies examine the role of nicotine replacement therapies in reducing aggregate tobacco consumption and increasing quitting. Hu et al. (2000) estimate that a 10 percent increase in sales of nicotine replacement products reduces cigarette sales by 0.04 percent. They estimate that, when nicotine patches became available in 1992 (as opposed to nicotine gum), cigarette sales fell by an additional 0.076 percent. Keeler et al. (2002) estimate that, when the FDA allowed smoking cessation products to be sold over-the-counter (OTC), consumption of nicotine patches and gum increased 78 - 92 percent and 180 percent respectively. Under the assumption that the products were as effective in practice as found in clinical trials, they estimate the extra sales translated into almost 20,000 extra quits in 1995. Burton et al. (1997) study the impact of the 1996 Great American Smokeout (GASO), sponsored by the American Cancer Society in collaboration with a manufacturer of nicotine medications. Using Nielsen data they estimate that paid advertisements that mentioned the GASO reached 122 
million adults. Burton et al. (1997) also estimate that purchases of nicotine medications increased by 11 percent around the 1996 GASO, but they can not tie that increase specifically to the impact of GASO advertising.

\section{The Regulatory Environment}

In addition to documenting the introduction of smoking cessation products, Table 1 also lists two types of other important regulatory decisions that affect their advertising. The first type is the FDA's decision of whether the product may be sold OTC. During the latter half of the 1990s, the FDA moved nicotine gum and nicotine patches from prescription to over-the-counter (OTC) status. The second type is the FDA's decision of how to regulate the advertising of products that are sold by prescription only.

FDA decisions to permit firms to sell their products OTC obviously affect the product costs faced by consumers. Less obviously, these decisions also affect the advertising costs faced by firms. Advertising costs fall because advertising of OTC products carries a lower regulatory burden than does advertising of prescription only products.

This lower regulatory burden flows from the agency with whom regulatory authority rests for each type of product. The FDA has regulatory authority over advertising of prescription drugs. That authority flows from The Food, Drug and Cosmetic Act (FDCA) of 1938 (52 Stat. 1040; 21 U.S.C. §301, et seq.) (hereafter “the Act”). Although the Act focuses on labeling and does not specifically define what constitutes advertising, the Act defines labeling to include all 'written, printed, or graphic' materials that accompanies the product. The FDA interpreted this language broadly to mean that they have the authority to regulate any material associated with a product, even if it does not physically accompany the product, as is the case for print or 
broadcast advertising. In Kordel v. United States the US Supreme Court upheld the FDA's interpretation and effectively granted the FDA regulatory authority over the advertisements for prescription drugs. Under this authority the FDA requires that advertisements for prescription drugs must contain "other information in brief summary relating to side effects, contraindications, and effectiveness.” ${ }^{5}$ By contrast the Federal Trade Commission (FTC), which has regulatory authority over advertising claims for OTC products, does not require disclosures of the above sort. In regulating advertising, the FTC generally requires only that advertisements are not false or deliberately misleading and that advertisers are able to substantiate claims.

FDA regulations make it more expensive to advertise prescription products because, to meet the FDA disclosure requirements, firms must accompany each advertisement with the sections of the labeling the FDA approved that discuss the product's adverse event profile, contraindications, warnings and precautions. As seen in Figure 1, in practice the typical advertisement of a prescription product for smoking cessation includes at least a page of fine print disclosures. The disclosures are not required by the FTC.

Table 1 also lists FDA’s decisions - in 1983, 1985, and 1997 - that have affected the advertising of products that are sold by prescription only. Over the decade of the 1970s and early 1980s pharmaceutical firms increasingly marketed prescription drugs by advertising directly to consumers. In 1983, before pharmaceutical products for smoking cessation were on the market, the FDA reacted to this trend. The FDA asked the manufacturers to voluntarily stop DTC advertising. The FDA asked for this moratorium because they wanted time to study whether or under what conditions DTC advertising might meet the statutory requirements of the

\footnotetext{
${ }^{5} 21$ U.S.C. 352(n).
} 
act.

The advertising of smoking cessation products was directly affected in 1985, when the FDA withdrew their request for the voluntary moratorium, but simultaneously imposed significant restrictions on DTC advertising. In particular, the FDA required DTC advertisements to meet the same standards as advertisements directed towards physicians. This standard required that advertisements that made safety and efficacy claims about a particular drug must include a brief summary of the product's side effects, contraindications, and effectiveness. ${ }^{6}$ The 1985 FDA disclosure requirements applied to DTC advertisements in both print and broadcast media. Although the disclosure requirement for broadcast advertisements was shorter, it still had to meet the FDA standard of being “adequate.” Moreover, broadcast advertisements would be required to make provisions for viewers to obtain the detailed FDA prescribing information. Meeting these disclosure requirements in broadcast advertisements was generally impractical. The general regulatory environment significantly changed again in 1997, when the FDA substantially reduced the burden of disclosure for broadcast DTC advertisements of pharmaceuticals. In 1995 the FDA had issued a notice of public hearing and request for comments on the regulation of DTC advertisements. ${ }^{7}$ Following this public hearing and the receipt of public comments, on August $12^{\text {th }}, 1997$ the FDA issued draft guidance for industry with respect to DTC advertising. ${ }^{8}$ The intended purpose of this guidance was to "enable product

${ }^{6}$ Section 202.1(e)(5)ii of the Federal Food, Drug and Cosmetic Act.

${ }^{7}$ See Department of Health and Human Services: Docket No. 95N-0227

${ }^{8}$ See Department of Health and Human Services: Docket No. 97D-0302. It is reasonably clear from the request for comments that the FDA was contemplating relaxed disclosure requirements for the adequate provision elements of the regulations. 
sponsors to fulfill the requirements for consumer-directed broadcast advertisements, while providing consumers with required risk information about the advertised product.” The requirements for print disclosure did not change.

While the new guidance surrounding broadcast advertising did not involve any formal regulatory action, it did create a new relatively safe harbor for manufacturers with respect to how FDA would interpret disclosure requirements. The 1997 FDA draft guidance continued to require manufacturers to include in all broadcast advertisements a major statement of the most important risks. The guidance suggested that manufactures could meet the requirement of providing detailed FDA prescribing information through toll-free telephone numbers, web sites, and references to labeling information in print advertisements appearing concurrently. The draft guidance required that broadcast advertisements should also indicate that health care professionals can provide additional information. ${ }^{9}$

Many observers believe the 1997 FDA regulatory change led to a sharp increase in DTC broadcast advertisements. The pharmaceutical industry's spending on DTC advertising tripled between 1996 and 2000, increasing from $\$ 791$ million to almost $\$ 2.5$ billion (Rosenthal et al. 2002). Even more dramatically, the industry's spending on television advertising increased more than seven-fold, from $\$ 220$ million to about $\$ 1.6$ billion. Rosenthal et al. (2002) note that the initial surge in DTC advertising preceded the FDA's release of draft guidelines in 1997, and suggest that these guidelines may not have been the most important reason for the overall increase. However, the FDA had announced a review of its approach in 1995 and some sort of reform was generally anticipated. Hence, it is perhaps not surprising that expenditures began to

${ }^{9}$ The 1997 draft guidance was amended slightly in 1999. 
increase even before the more official notification in 1997 of the change in regulatory approach.

Further regulatory changes may be in the air, but it is not clear in which direction the regulatory winds are blowing. In 2003, the FDA reviewed its regulatory approach to DTC advertising. The FDA review process included a request for comments from federal agencies, corporations and lobbying groups with an interest in DTC regulatory matters. The FTC's written comments in response to this request suggested that the FDA should drop its requirement that pharmaceutical print advertisements include detailed drug side-effects listings, in favor of allowing the same kind of "brief summary" risk warnings in print advertisements that are now used in broadcast commercials. More generally, the FTC urged the FDA not to impede DTC pharmaceutical advertising. In 2004, the FDA issued draft guidance suggesting that a briefer print disclosure can be appropriate, but no final rule has been issued and it is unclear if the draft guidance provides a safe harbor for firms to use abbreviated disclosures.

\section{Data}

We use two main sources of data on DTC advertising of nine smoking cessation products: Nicorette Gum; Nicoderm CQ Patch; Habitrol Patch; ProStep Patch; Nicotrol Patch; Nicotrol Inhaler; Zyban (buproprion); and Commit (nicotine lozenge). First, we use data on advertising expenditures by product category, for both print and broadcast media. We use the "Media Intelligence” advertising expenditure data from Competitive Media Reporting [CMR]. The series runs from 1986 - 2002. The Consumer Price Index is used to express the expenditure data in constant 2002 dollars.

The second main source of data is an archive of pharmaceutical product DTC

advertisements in the print media. The Smoking Cessation Advertisements (SCADS) Archive 
includes all advertisements for smoking cessation products that appeared in any issue of 26 consumer magazines and two medical journals between January 1985 and May 2002, yielding a sample of 13,497 issues. The data measure each advertisement's brand, the length of advertisement in standardized pages, and the data of the issue of each magazine in which it appears. The SCADS Archive is discussed in more detail in the Data Appendix.

Figure 2 shows trends in total expenditures on smoking cessation product advertisements from 1986 to 2002. Advertising expenditures are fairly low from 1986 through 1991, after which advertising expenditures spiked up to about $\$ 100$ million, driven by the introduction and intensive marketing of the first nicotine patches. After returning to lower levels, beginning around 1995 advertising expenditures increase again. The 1996-1999 spike roughly coincides with the relaxation of FDA regulations on DTC advertising in broadcast media; however it also coincides with the introduction of new products (nicotine nasal spray, nicotine inhaler, and buproprion), and the conversion of older products from prescription-only to OTC status. Total advertising expenditures hit about $\$ 200$ million at their peak in 1999. It is also notable that after 1995 the composition of expenditures shifted dramatically towards television. In 1992, print media advertisements account for about 80 percent of total expenditures, while broadcast media account for only 20 percent. In 1999, broadcast media advertisements account for about 90 percent of total expenditures. However, advertising in both broadcast and print media initially increase after 1995. In the last few years of our study period, expenditures on both print and television advertising fall.

Figure 3 compares total advertising expenditures for the smoking cessation products with the number of pages advertisements for each product that appear in our archive. In addition to 
helping document the trends, Figure 2 shows that there is a very strong relationship between total advertising expenditures and the SCADS advertising data. The first peaks in both series occur in 1992 around the introduction of the nicotine patch, with about 400 pages of archived print advertisements for smoking cessation products. As with expenditures, the number of pages increases again from 1995 - 1999, peaking at about 200 pages in 1997 and 1998. In some years during the 1980s, our archive contains print advertisements for smoking cessation products even though the CMR data show zero print media advertising expenditures. This appears to be an artifact of the CMR data, where small levels of expenditures are either missed or collapsed into a non-itemized category. At the very end of our study period, the CMR data show substantial expenditures in 2002 on print media advertisements of the newly-introduced Commit nicotine lozenge. However, the SCADS archive ends in May 2002, before the October 2002 launch of Commit. For most of the period and most of the products, the SCADS archive appears to be representative of the universe of all smoking cessation product advertisements in magazines.

Table 2 provides an overview of how the advertisements in the SCADS archive are distributed across the consumer and medical magazines, and across prescription versus OTC products. About three quarters of the slightly more than 1000 advertisements for smoking cessation products appear in the 26 consumer magazines, while the two medical journals account for the other quarter of all advertisements. About three quarters of the advertisements are for prescription products, with about twice as many of these advertisements appearing in the consumer magazines than in the medical journals. Even afer products are available OTC they are still advertised in the medical journals, but it is clear that the advertising effort shifts more towards the consumer magazines. It should be kept in mind that while there are more 
advertisements for prescription products than for OTC products, for much of our sample period there were also more prescription products on the market.

\section{Econometric Model of Advertising and Hypotheses to be Tested}

In this section we develop an econometric model to estimate the impact of the regulatory environment and other market-level forces on the advertising of smoking cessation products. The model and hypotheses to be tested are based on a profit-maximizing framework. We follow a standard approach and assume that a firm in an oligopolistic or monopolistically competitive industry advertises to invest in a stock of consumer knowledge (Roberts and Samuelson 1988, Chintagunta and Vilcassim 1994, Lee 2002, Bhattacharya and Vogt 2003). For smoking cessation products, advertising may increase consumer demand both by informing consumers about the health benefits of smoking cessation, and by informing consumers about the availability and efficacy of the advertised product. Advertising thus increases the firm's total revenues by increasing consumer demand for its product. As Berndt et al. (1995) note, for pharmaceutical products marginal production costs are low, so shifting out consumer demand is essentially the same as increasing profits.

The first order conditions for profit maximization, which require that the marginal revenues from advertising are set equal to the marginal costs of advertising, implicitly define the firm's input demand function for advertising. This motivates the specification of our econometric model given by equation (1), which can be thought of as a version of an input demand function, where advertising demand depends on the costs of advertising and the market environment:

(1) Advertising $_{\mathrm{p}(\mathrm{m}) \mathrm{t}}=\alpha_{\mathrm{o}}+\alpha_{1}$ OTC Status $_{\mathrm{pt}}+\alpha_{2}\left(\right.$ OTC Status $\left._{\mathrm{pt}}\right) *(\mathrm{JAMA})+\alpha_{3}(\mathrm{OTC}$ 


$$
\begin{aligned}
& \text { Status } \left._{\mathrm{pt}}\right) *(\mathrm{NEJM})+\alpha_{4} \text { Introductory Period } \mathrm{pt}+\beta \text { Year Dummies }+\gamma \text { Month Dummies } \\
& +\delta \text { Magazine Dummies }+\zeta \text { Product Dummies }+\mathrm{e}_{\mathrm{pmt}}
\end{aligned}
$$

We estimate equation (1) using different measures of advertising as the dependent variable: expenditures on print media advertisements for product $\mathrm{p}$ in month $\mathrm{m}$; expenditures on television advertisements for product $\mathrm{p}$ in month $\mathrm{t}$; the number of print media advertisements for product $\mathrm{p}$ in magazine $\mathrm{m}$ during month $\mathrm{t}$; and the number of pages of print media advertisements for product $\mathrm{p}$ in magazine $\mathrm{m}$ during month $\mathrm{t}^{10}$ Our approach to understand the economic determinants of smoking cessation product advertising exploits variation in the costs of advertising over time and across products created by the regulatory environment. Equation (1) also includes sets of dummy variables for year, month, and product. When the dependent variables are the number and pages of magazine advertisements, the models also include a set of magazine dummies; the dummies for the two medical journals - the Journal of the American Medical Association (JAMA) and the New England Journal of Medicine (NEJM) - are also interacted with the measure of OTC status. The various dummies are included to capture other important aspects of the market environment and the costs of advertising. ${ }^{11}$ Table 3 provides the

${ }^{10}$ Our unit of observation is chosen to be the number of advertisements or pages per month because some of the magazines in our sample are monthly magazines. For those magazines that are weekly we add the value of the dependent variable across the 4 (or 5) weekly issues that have that month on the date of the publication.

${ }^{11}$ The year dummies capture general time trends as well as the degree of competition in the market for smoking cessation products; below, we further explore the role of competition in equation (2) by replacing the set of year dummies with a specific parameterization of the effect of time. In equation (1), the magazine dummies capture the price of advertising space as well as 
means of the dependent and independent variables.

We hypothesize that the marketing status of the product (prescription versus OTC) will be an important factor in a firm's decision to advertise. In our empirical models, we capture this aspect of the regulatory environment by the variable OTC Status ${ }_{p t . .}$ This variable indicates if product $\mathrm{p}$ at time $\mathrm{t}$ is available over-the-counter. OTC status is hypothesized to generate a number of influences, most of which will tend to increase advertising. First, we expect an ownprice effect: the removal of disclosure requirements lowers the costs of advertisements and thus increases firms' demand for advertising. Second, by eliminating the need to see a physician, OTC status lowers the full costs consumers face to obtain smoking cessation products, which can be expected to increase consumer demand, thus increasing the returns to advertising. ${ }^{12}$ Third, OTC status may make advertising more effective: because firms are no longer required to disclose side effects so prominently, consumers may be more likely to respond to advertisements. A change to OTC status may also work in the other direction and cause certain types of advertising to decrease. A cross-price effect might tend to decrease magazine advertising: because OTC status decreases the relative cost of television advertising, firms may

other aspects of a particular magazine such as total circulation and readership demographics.

${ }^{12}$ Because of health insurance, in principle the switch to OTC can have ambiguous effects on the return to advertising. Insured consumers may actually see lower out-of-pocket costs when the drug is available by prescription only. Moreover, health insurance coverage will tend to make demand more price inelastic, increasing manufacturers' expected returns on advertising (Danzon and Pauly 2002, pp. 608-609). For some drugs, therefore, a switch to OTC status may reduce demand and make demand more price elastic, thus reducing the returns to advertising. However, health insurance coverage of prescription drugs for smoking cessation was uncommon for most of the period we study (McPhillips-Tangum 1998, National Center for Health Statistics 2001), and empirical evidence suggests that the switch of these drugs to OTC status shifted the demand curve out (Keeler et al. 2002). 
substitute away from magazine advertising into television. Finally, we expect that OTC status reduces the returns to advertising targeted at physicians, so in the models of the number and pages of magazine advertisements we include interactions with the dummy variables for the two medical journals (JAMA and NEJM).

The FDA also influences the market for smoking cessation advertising through its initial approval to allow new products on the market. Equation (1) includes a variable Introductory Period $_{p t}$, which is defined as the six month period following approval. This allows us to test Bhattacharya and Vogt's (2003) theoretical prediction that pharmaceutical advertising levels are set high early in the product’s life cycle to build public knowledge about the product.

To further explore the economic determinants of advertising choices, we re-specify equation (1) by replacing the set of year dummies with a specific parameterization of the effect of time:

$$
\begin{aligned}
& \text { Advertising } \left._{\mathrm{pmt}}=\alpha_{\mathrm{o}}+\alpha_{1} \text { OTC Status }_{\mathrm{pt}}+\alpha_{2} \text { (OTC Status }_{\mathrm{pt}}\right) *(\text { JAMA })+\alpha_{3} \text { (OTC Status }_{\mathrm{pt}} \\
& )^{*}(\mathrm{NEJM})+\alpha_{4} \text { Introductory Period }_{\mathrm{pt}}+\beta_{1} \text { Number of products on } \text { market }_{\mathrm{t}}+\beta_{2} \\
& (\text { Number of products on market })^{2}+\beta_{3} \text { Post } 1997 \text { Regulations }+\beta_{4}\left(\text { Rx Status }_{\mathrm{pt}}\right) *\left(\text { Post }^{2}\right. \\
& 1997 \text { Regulations })+\gamma \text { Month Dummies }+\delta \text { Magazine Dummies }+\zeta \text { Product Dummies } \\
& +\mathrm{e}_{\mathrm{pmt}}
\end{aligned}
$$

To capture the potential impact of brand competition on the returns to advertising, equation (2) includes the number of smoking cessation products on the market at time t, and the square of this measure. This allows us to test the conventional wisdom about the relationship between competition and advertising - "the so-called inverted U hypothesis, which implies that 
moderately concentrated industries engage more intensively in advertising than both atomistically competitive and highly concentrated industries.” (Lee 2002, pp. 89 - 90). In other contexts, the measures of the market environment might be endogenous to advertising levels, but this does not seem likely in the market for smoking cessation products. An incumbent's advertising might discourage entry (Schmalensee 1983), reducing the number of products on the market. Scott Morton's (2000) empirical analysis suggests that brand advertising is not a barrier to entry by generic firms into the U.S. pharmaceutical market. Over most of the period we study, entry into the market for smoking cessation products did not involve generics but instead involved the introduction of new branded products. Introduction of these products was the last step of a long process of development and testing begun long before current advertising could be known. The exact timing of FDA approval is also not a choice variable of the firm. For this reasons, we believe it is appropriate to treat the measures of the market environment as exogenous to current advertising choices.

Equation (2) also introduces another regulatory variable, Post 1997, which indicates if the observed advertisement occurs after the FDA 1997 regulatory change for broadcast advertising. By lowering the cost of broadcast advertising, we predict own-price effects that will increase the demand for television advertising and possible cross-price effects to reduce demand for magazine advertising. Because the 1997 regulatory change applied to prescription products, Post $1997_{t}$ is interacted with an indicator variable for whether the product is available only by prescription at time t.

To estimate our models of advertising expenditures, we use a sample of 998 observations of the advertising expenditures for each product in each month it was on the market from 
January 1985 to December 2002. The models are estimated by ordinary least squares (OLS).

We also estimate a two part model, where the first part is a probit model of the probability that advertising expenditures were positive, and the second part is an OLS model of the log of expenditures for the sub-sample with positive expenditures. When we estimate models of magazine advertisements, our sample consists of the number (pages) of advertisements that appear in each SCADS magazine in each month a product was on the market from January 1985 to May 2002. Our SCADS sample consists of 25,021 observations. We estimate the models of the number and pages of magazine advertisements by OLS. ${ }^{13}$

\section{Results}

Tables 4 and 5 present estimates of equations (1) and (2) for our models of advertising expenditures; Table 6 presents estimates of equations (1) and (2) for our models of the number and pages of magazine advertisements. The results suggest that a firm's decision to advertise is significantly affected by FDA regulation of whether a product is available by prescription-only or OTC. OTC status is associated with an increase in expenditures for advertising in both magazines and television. For magazine advertising, the two-part model results suggest that

\footnotetext{
${ }^{13}$ The dependent variables for these models are counts of the number of advertisements and the number of pages of advertisements. The Poisson model, an extension of the regression model that is appropriate when the dependent variable is a count rather than a continuous variable, relies on restrictive assumptions that are problematic for our data. For example, about 98 percent of the observations of the number of advertisements take the value of zero, while the nonzero values range from 1 to 10 . This suggests there may be "excess zeros" and/or “overdispersion” (Mullahy 1997, Wooldridge 2002). Wooldridge (2002, p. 651) cautions that "In the case of overdispersion, the standard errors [on the coefficients from the standard Poisson model] ... will systematically underestimate the asymptotic standard deviations, sometimes by a large factor." We therefore adopt OLS as a more conservative approach. We have also collapsed the dependent variables to 0-1 measures of any advertisements or any pages. Probit models using these variables yield similar results to the OLS models reported; the probit results are available upon request.
} 
most of the effect is through the probability of any expenditures rather than on the amount of expenditures conditional on positive advertising. For television advertising, OTC status is associated with an increase in both parts of the expenditures model. In Table 6, OTC status is also associated with an increase in the number of magazine advertisements and an increase in the pages of advertisements, although the latter effect is not quite statistically significant when the year dummies are replaced with the parameterized time trend. Not surprisingly, when a product becomes available OTC, manufacturers reduce the number and pages of advertisements for that product in the two medical journals (JAMA and NEJM).

Because OTC magazine advertisements no longer include the full page of disclosures, it would have been possible for manufactures to increase the number of advertisements while holding constant or even decreasing total expenditures and the pages of advertisements. The fact that total expenditures and the number of pages of advertisements instead actually increase suggest that advertising demand is quite responsive to the own-price effects and other influences created by OTC status.

To shed more light on the practical significance of the OTC effect, we can use our models to predict the amount of magazine advertising under two hypothetical policy regimes. The first, admittedly radical, simulated policy change assumes that the FDA allowed all products to be immediately sold OTC rather than by prescription only. This would result in an approximate tripling of the number of observations of OTC products in our sample. Our model predicts that this change would increase the number of advertisements for smoking cessation products by 80 percent, from 1069 to 1921 total advertisements. Our second simulation considers a much more modest change. Suppose that, for each product currently sold OTC, the 
FDA approved it for OTC sale exactly one year before the actual approval date. This hypothetical policy change would increase the number of observations of OTC products by about twenty percent. According to our model, this change would increase the number of magazine advertisements by a little less than nine percent, from 1069 to 1160 advertisements.

Our results also show that the FDA's decisions to approve new products affects advertising in two ways: through initial advertising during the introductory period; and through effects on market competition. All of the models reported in Tables 4, 5 and 6 show a large introduction effect. Consistent with the prediction of Bhattacharya and Vogt (2003), advertising is much higher during the 6 month introductory period. We also find that when a product vies against more competing products, firms advertise more, but the increase in advertising associated with each additional competitor falls as more products come onto the market. This result fits the inverted-U hypothesis. During the period under study, the market for smoking cessation products evolved from a highly concentrated industry (when nicotine gum was the only approved pharmaceutical product on the market) into a less concentrated industry. The estimated coefficients from our model imply that the maximum amount of advertising occurs with about four to five products on the market, a level of competition reached around the time several different manufacturers introduced the nicotine patch in 1991 - 1992. Although the introduction effect and the competition effect are affected by FDA regulatory decisions, it is hard to develop reasonable counter-factuals for policy simulations. That is, earlier or later FDA approval would change the timing of the introduction effect and the date when advertising is maximized, but would not necessarily change the total advertising over the entire period.

Results in Table 5 show that the 1997 regulatory change increased expenditures on 
television advertising of prescription smoking cessation products. Because the 1997 regulatory change made it much easier to advertise on television, this pattern is expected and is consistent with other research (Rosenthal et al. 2002). However, the results in Tables 4 and 6 do not provide consistent evidence of a strong impact of the 1997 regulatory change on the demand for magazine advertising. This may not be that surprising because the current regulatory environment tends to induce a complementarity between the two forms of advertising. Some types of advertisements for prescription products on television must refer the customer to a print advertisement - where the full disclosure continues to be required.

Although not reported in the Tables, we also estimated equation (1) parameter vectors $\beta$, $\gamma, \delta$ and $\zeta$ corresponding to the vectors of year, month, magazine, and product dummy variables. An interesting pattern from these estimates is that advertising is highest in January and November. This pattern suggest that the manufacturers of smoking cessation products may perceive greater returns to advertising in months when smokers are pre-disposed to quit because of New Year's resolutions and the Great American Smokeout. There also seems to be evidence of 'summer doldrums,' with less advertising of the products in June, July and August.

\section{Conclusion}

Our results provide strong evidence that a switch to OTC status is associated with increased advertising of smoking cessation products. This evidence sheds new light on the FTC's December 2003 recommendation that the FDA should change its disclosure requirements for pharmaceutical print advertisements. If the FDA adopts this recommendation, requirements for all DTC advertisements of prescription pharmaceuticals would be similar to current requirements for advertisements of OTC products. Our results suggest the new regulatory stance 
could substantially increase DTC advertising of pharmaceuticals.

Of course, there are different views of whether more DTC advertising of pharmaceuticals will improve consumer welfare. The general debate on DTC advertising is beyond the scope of this paper. However, it should be noted that standard objections to DTC advertising do not seem to carry as much weight in the context of smoking cessation products. For example, a common concern is that patients may incorrectly self-diagnose and pressure physicians for inappropriate prescriptions for non-existent conditions. Such a situation seems unlikely for smokers. ${ }^{14}$ The wide availability of nicotine replacement products in the late 1990s has been credited with producing "the largest increase in smoking cessation since the 1964 Surgeon General's report on smoking.” (Hughes 2000, p. 147). Because de-regulating the advertising of smoking cessation products is likely to help more smokers quit, such a regulatory change can also improve public health. In on-going work, we are exploring whether advertising of smoking cessation products translates into more ex-smokers. The results of our on-going research will allow us to quantify the public health benefits of changes to the FDA's DTC advertising regulations.

${ }^{14}$ There is some concern that non-smokers will use nicotine replacement products. Because virtually all of the adverse health consequences of smoking are due to the inhaled smoke, and not the nicotine per se, it is not clear that this small potential cost of advertising smoking cessation products could outweigh the benefits of increased cessation. 


\section{References}

Berndt, Ernst R., Linda Bui, David R. Reiley, and Glen L. Urban (1995). “Information, Marketing, and Pricing in the U.S. Antiulcer Drug Market.” American Economic Review Papers and Proceedings 85 (2): 100 - 105.

Bhattacharya, Jayanta and William B. Vogt (2003). “A Simple Model of Pharmaceutical Price Dynamics.” Journal of Law and Economics XLVI: 599- 626.

Bulow, Jeremy and Peter Klemperer (1998). “The Tobacco Deal.” Brookings Papers on Economic Activity: Microeconomics, 323-394.

Burton, SL, and others (1997). “Impact of Promotion of the Great American Smokeout and Availability of Over-the-Counter Nicotine Medications, 1996.” Morbidity and Mortality Weekly Report 46 (37): 867 - 869.

Calfee, John E. (2002). “Public Policy Issues in Direct-to-Consumer Advertising of Prescription Drugs.” Journal of Public Policy and Marketing 21, (2) 174-194.

Calfee, John E., Clifford Winston, and R. Stempski (2003). “Direct-to-Consumer Advertising and the Demand for Cholesterol-Reducing Drugs.” Journal of Law and Economics 45 (2, Part 2): 673-690.

Chaloupka, Frank J. and Kenneth Warner (2000). "The Economics of Smoking." Handbook of Health Economics, Joseph Newhouse and Anthony Culyer, Editors. (North-Holland)

Chintagunta, Pradeep K. and Naufel J. Vilcassim (1994). "Marketing Investment Decisions in a Dynamic Duopoly: A Model and Empirical Analysis.” International Journal of Research in Marketing 11: 287-306. 
Danzon, Patricia M. and Mark V. Pauly (2002). “Health Insurance and the Growth in Pharmaceutical Expenditures.” Journal of Law and Economics, XLV.

Gallet, Craig A., and John A. List (2003). “Cigarette Demand: A Meta-Analysis of Elasticities.” Health Economics 12: 821-835.

Gruber, Jonathan (2001). “Tobacco at the Crossroads: The Past and Future of Smoking Regulation in the United States.” Journal of Economic Perspectives 15 (2): 193-212. HarpWeek (2004). Web page accessed July 27, 2005.

Http://tobacco.harpweek.com/HubPages/CommentaryPage.asp?Commentary=Addiction.

Hays, Taylor J., Ivana T. Croghan, Darrell R. Scchroeder, Keneth P. Offord, Richard D. Hurt, Troy D. Wolter, Mitchell A. Nides and Michael Davidson (1999). “Over-The Counter Nicotine Patch Therapy for Smoking Cessation: Results From Randomized, DoubleBlind, Placebo-Controlled, and Open Label Trials.” American Journal of Public Health 89 (11): 1701-1707.

Hu, Teh-Wei, Hai-Yen Sung, Theodore E. Keeler and Martin Marciniak (2000). “Cigarette Consumption and Sales of Nicotine Replacement Products.” Tobacco Control 9:60-63. Hughes, John R. (2000). “New Treatments for Smoking Cessation.” CA Cancer Journal for Clinicians 50 (3): 143-151.

Ippolito, Pauline M. and Alan Mathios (1990) “Information, Advertising and Health Choices: A Study of the Cereal Market.” RAND Journal of Economics 21 (3):459-480.

Ippolito, P., and Mathios, A., (1991) "Health Claims in Food Marketing: Evidence on Knowledge and Behavior in the Cereal Market," Journal of Public Policy and Marketing, 10(1):15-32. 
Ippolito, P. and Mathios, A., (1995) "Information and Advertising: The Case of Fat Consumption in the United States," American Economic Review: Papers and Proceedings, 85 (2), 91-95.

Iizuka, Toshiaki and Ginger Z. Jin (2002). "The Effects of Direct-to-Consumer Advertising in the Prescription Drug Market.” Working Paper.

Keeler, Theodore E., Teh-wei Hu, Allison Keith, Richard Manning, Martin Marciniak, M. Ong, and Hai-yen Sung (2002). “The Benefits of Switching Smoking Cessation Drugs to Over-the-Counter Status.” Health Economics 11 (5): 389-402.

Keith, Alison (1995). “Regulating Information About Aspirin and the Prevention of Heart Attack.” American Economic Review Papers and Proceedings 85 (2): 96-99.

Lee, Chang-Yang (2002). “Advertising, Its Determinants, and Market Structure.” Review of Industrial Organization 21: 89-101.

Lexchin, Joel and Barbara Mintzes (2002). "Direct-to-Consumer Advertising of Prescription Drugs: The Evidence Says No.” Journal of Public Policy and Marketing 21 (2): 194-201. Lewit, Eugene, Douglas Coate and Michael Grossman (1981). “The Effects of Government Regulation on Teenage Smoking.” Journal of Law and Economics, 24 (3): 545-69. Ling, Davina C., Ernst R. Berndt, and Margaret K. Kyle (2002). “Deregulating Direct-toConsumer Marketing of Prescription Drugs: Effects on Prescription and Over-theCounter Product Sales.” Journal of Law and Economics, 45 (2): 691-723.

Ma, J, R S Stafford, I M Cockburn, and S N Finkelstein (2003). “A Statistical Analysis of the Magnitude and Composition of Drug Promotion in the United States in 1998.” Clinical Therapeutics 25 (5): 1503-1517. 
Mathios, Alan, (1996) "Socioeconomic Factors, Nutrition, and Food Choices: An Analysis of the Salad Dressing Market,"Journal of Public Policy and Marketing, 15 (1).

Mathios, Alan, (1998) “The Importance of Nutrition Labeling and Health Claim Regulations on Product Choice: An Analysis of the Cooking Oil Market,” Agricultural and Resource Economics Review.

Mathios, Alan, (2000) “The Impact of Mandatory Disclosure Laws on Product Choices: An Analysis of the Salad Dressing Market,” Journal of Law and Economics, 43 (2), October.

McPhillips-Tangrum, C. (1998). Results from the first annual survey on addressing tobacco in managed care. Tobacco Control 7:S11-S13, 1998.

Mendez, David and Kenneth E. Warner (2000). “Smoking Prevalence in 2010: Why the Healthy People Goal is Unattainable.” American Journal of Public Health 90: 401-403.

Mendez, David and Kenneth E. Warner (2004). “Adult Cigarette Smoking Prevalence: Declining as Expected (Not as Desired).” American Journal of Public Health 94 (2): 251-252.

Mintzes, Barbara (2001). An Assessment of the Health System Impacts of Direct-to-Consumer Advertising of Prescription Medicines. Health Policy Research Unit, Centre for Health Services \& Policy Research, University of British Columbia.

Mullahy, John (1997). "Heterogeneity, Excess Zeros, and the Structure of Count Data Models.” Journal of Applied Econometrics 12: 337-350.

National Center for Health Statistics (2001). Healthy People 2000 Final Review. Hyattsville, Maryland: Public Health Service. 
Nelson, Jon P. (2003). "Cigarette Demand, Structural Change, and Advertising Bans: International Evidence, 1970-1995", Contributions to Economic Analysis \& Policy Vol. 2: No. 1, Article 10.

Plassman, Vandana, Donald Kenkel, Dean Lillard, and Alan Mathios (2005). “Socioeconomic Differences in Smoking Cessation.” Working Paper, Department of Policy Analysis and Management, Cornell University.

Roberts, Mark J. and Larry Samuelson (1988). “An Empirical Analysis of Dynamic, Nonprice Competition in an Oligopolistic Industry.” RAND Journal of Economics 19 (2): 200 220.

Rosenthal, Meredith B., Ernst R. Berndt, Julie M. Donohue, Richard G. Frank, and Arnold M. Epstein (2002). “Promotion of Prescription Drugs to Consumers,” New England Journal of Medicine 346 (7): 498 - 505.

Rosenthal, Meredith B., Ernst R. Berndt, Julie M. Donohue, Arnold M. Epstein, and Richard G. Frank (2003). “Demand Effects of Recent Changes in Prescription Drug Promotion.” In Frontiers in Health Policy Research, Vol. 6, edited by Alan M. Garber and David M. Cutler. Cambridge, Mass.: MIT Press (for National Bureau of Economic Research). Saffer, Henry and Frank Chaloupka (2000). “The Effects of Tobacco Advertising Bans on Tobacco Consumption.” Journal of Health Economics 19 (6): 1117- 1137.

Schmalensee, R. (1983). “Advertising and Entry Deterrence: An Exploratory Model.” Journal of Political Economy 91: 636-653. 
Schoenborn, Charlotte A, Jackline L. Vickerie, and Patricia M Barnes (2003). “Cigarette Smoking Behavior of Adults: United States 1997-98,” Advance Data from Vital and Health Statistics Number 331, February 7.

Schneider, Lynne, Benjamin Klein, and Kevin M. Murphy (1981). “Governmental Regulation of Cigarette Health Information.” Journal of Law and Economics 24 (3):575-612.

Schwartz, Jerome L. (1987). Review and Evaluation of Smoking Cessation Methods: The United States and Canada, 1978-1985. Published by Division of Cancer Prevention and Control, National Cancer Institute, U.S. Department of Health and Human Services. NIH Publication No. 87-2940.

Scott Morton, Fiona M. (2000). “Barriers to Entry, Brand Advertising, and Generic Entry in the US Pharmaceutical Industry.” International Journal of Industrial Organization 18: 1085-1104.

Shiffman, Saul, Joe Gitchell, John M. Pinney, Steven L. Burton, Katherine E. Kemper, and Eduardo A. Lara (1997). "Public Health Benefit of Over-the-Counter Nicotine Medications.” Tobacco Control 6: 306-310.

Silk, Alvin J., Lisa R. Klein, and Ernst R. Berndt (2002). “Intermedia Substitutability and Market Demand by National Advertisers.” Review of Industrial Organization 20: 323348.

Sloan, Frank A., V. Kerry Smith, and Donald H. Taylor, Jr. (2002). "Information, Addiction, and 'Bad Choices': Lessons from a Century of Cigarettes,” Economics Letters 77: 147155. 
Tauras, John A., and Frank Chaloupka (2003). “The Demand for Nicotine Replacement Therapies," Nicotine and Tobacco Research 5: 237-243.

U.S. Department of Health and Human Services [USDHHS]. 1989. Reducing the Health Consequences of Smoking. 25 Years of Progress. A Report of the Surgeon General. 1989. U.S. Department of Health and Human Service, Public Health Service, Centers for Disease Control, Center for Chronic Disease Prevention and Health Promotion, Office on Smoking and Health.

U.S. Department of Health and Human Services [USDHHS] (2000a). Reducing Tobacco Use: A Report of the Surgeon General. . Atlanta, Georgia: U.S. Department of Health and Human Service, Public Health Service, Centers for Disease Control and Prevention, National Center for Chronic Disease Prevention and Health Promotion, Office on Smoking and Health.

U.S. Department of Health and Human Services [USDHHS] (2000b). Healthy People 2010. $2^{\text {nd }}$ Edition. With Understanding and Improving Health and Objectives for Improving Health. 2 vols. Washington, DC: U.S. Government Printing Office.

U.S. Department of Health and Human Services [USDHHS] (2000c). Clinical Practice Guideline: Treating Tobacco Use and Dependence.

Wooldridge, Jeffrey M. (2002). Econometric Analysis of Cross Section and Panel Data. Cambridge, Massachusetts: The MIT Press.

Wosinska, Marta (2003). “Just What the Patient Ordered? Direct-to-Consumer Advertising and the Demand for Pharmaceutical Products.” Harvard Business School Working Paper No. 02-04. 
Wosinska, Marta (2005). “Direct-to-Consumer Advertising and Drug Therapy Compliance.” Journal of Marketing Research (Forthcoming). 


\section{TABLE 1: Events in the Development and Advertising of Smoking Cessation Products}

\begin{tabular}{|c|c|}
\hline Year & Event \\
\hline 1983 & $\begin{array}{l}\text { Food and Drug Administration (FDA) requests voluntary moratorium on direct-to-consumer } \\
\text { (DTC) advertising of prescription drugs }\end{array}$ \\
\hline 1984 & Nicorette $\bigodot$ Gum (2 mg) approved for prescription sale (January) \\
\hline 1985 & FDA lifts moratorium on DTC advertising (with significant restrictions). \\
\hline 1991 & $\begin{array}{l}\text { Nicoderm@ CQ Patch approved for prescription sale (September) } \\
\text { Habitrol@ Patch approved for prescription sale (September) }\end{array}$ \\
\hline 1992 & $\begin{array}{l}\text { ProStep@ Patch approved for prescription sale (January) } \\
\text { Nicorette@ Gum (4 mg) approved for prescription sale (June) } \\
\text { Nicotrol@ Patch approved for prescription sale (August) }\end{array}$ \\
\hline 1994 & Nicorette $\bigodot$ Gum patent expires \\
\hline 1995 & FDA invites comments on adequate disclosure requirements (August) \\
\hline 1996 & $\begin{array}{l}\text { Nicorette@ Gum (2 and } 4 \mathrm{mg} \text { ) approved for over-the-counter (OTC) sale (February) } \\
\text { Nicotrol@ Nasal Spray approved for prescription sale (March) } \\
\text { Nicotrol@ Patch approved for OTC sale (July) } \\
\text { Nicoderm@ CQ Patch approved for OTC sale (August) }\end{array}$ \\
\hline 1997 & $\begin{array}{l}\text { Nicotrol@ Inhaler approved for prescription sale (May) } \\
\text { Zyban@ } \odot \text { approved for prescription sale (May) } \\
\text { FDA relaxes disclosure requirements governing DTC advertising of prescription drugs on } \\
\text { television and radio }\end{array}$ \\
\hline 1998 & Nicorette Mint@ Gum (2 and 4 mg) approved for OTC sale (December) \\
\hline 1999 & $\begin{array}{l}\text { ProStep@ Patch approved for OTC sale (January) } \\
\text { Nicotrol@ Gum ( } 2 \text { and } 4 \mathrm{mg} \text { ) approved for OTC sale (March) } \\
\text { Habitrol@ Patch approved for OTC sale (November) } \\
\text { Combined Zyban@ / Nicotine transdermal systems patch therapy approved for prescription sale }\end{array}$ \\
\hline 2000 & Nicorette Orange $\odot$ Gum (2 and 4 mg) approved for OTC sale (September) \\
\hline 2002 & Commit Lozenge $\bigodot$ approved for OTC sale (October) \\
\hline 2003 & $\begin{array}{l}\text { Federal Trade Commission comments on FDA regulatory approach to DTC advertisements } \\
\text { (December) }\end{array}$ \\
\hline \multicolumn{2}{|c|}{$\begin{array}{l}\text { Source: authors' compilation from Food and Drug Administration archives. Lists of drug approval dates and } \\
\text { dates for movements to OTC status were obtained from the website http://www.fda.gov/opacom/7approvl.html } \\
\text { and from various newspaper and journal articles. Regulatory events surrounding direct-to-consumer advertising } \\
\text { are obtained from press releases on the FDA website and federal register documents. }\end{array}$} \\
\hline
\end{tabular}




\section{TABLE 2: Smoking Cessation Product Advertisements by Magazine Type and OTC}

Status

\begin{tabular}{|l|r|l|r|}
\hline & Consumer Magazines & Medical Journals & Total \\
\hline Prescription Products & 531 & 243 & 774 \\
\hline OTC Products & 245 & 50 & 295 \\
\hline Total & 776 & 293 & 1069 \\
\hline
\end{tabular}

Source: SCADS archive. Consumer Magazines include: Ebony, National Geographic, Better Homes \& Gardens, Sports Illustrated, Readers Digest, Time, Money, Modern Maturity, Family Circle, Women's Day, Cosmopolitan, YM, Rolling Stone, Good Housekeeping, Playboy, Glamour, Vibe, Seventeen, Newsweek, Jet, Business Week, TV Guide, People, U.S. News \&World Report, Entertainment Weekly, McCall's/Rosie and Essence. Medical Journals include: Journal of the American Medical Association and the New England Journal of Medicine. 


\section{TABLE 3: Descriptive Statistics}

\begin{tabular}{|l|c|}
\hline Variable & Mean \\
\hline $\begin{array}{l}\text { Expenditures on magazine advertising } \\
\text { (million \$) }\end{array}$ & 271.32 \\
\hline $\begin{array}{l}\text { Expenditures on television advertising } \\
\text { (million \$) }\end{array}$ & 925.17 \\
\hline Number of magazine advertisements & 0.043 \\
\hline Pages of magazine advertisements & 0.081 \\
\hline \begin{tabular}{l} 
OTC \\
\hline Introductory period
\end{tabular} & 0.357 \\
\hline Number of products on market & 0.053 \\
\hline Post 1997 & 6.746 \\
\hline Post 1997 * Rx Product & 0.515 \\
\hline $\begin{array}{l}\text { Notes: The mean of the first two variables in the table are derived from the } \\
\text { variables in the table are derived from the SCADS data with a sample size of } \\
\text { 25,021. }\end{array}$ & 0.203 \\
\hline
\end{tabular}




\begin{tabular}{|c|c|c|c|c|c|c|}
\hline & \multicolumn{3}{|c|}{ With Year Effects } & \multicolumn{3}{|c|}{ Parameterized Time Trend } \\
\hline & OLS (\$) & Probit $(\$>0)$ & OLS $(\log \$>0)$ & OLS (\$) & Probit $(\$>0)$ & OLS $(\log \$>0)$ \\
\hline OTC & $\begin{array}{l}344.26 * * * \\
(3.63)\end{array}$ & $\begin{array}{c}0.355^{* * *} \\
(4.69)\end{array}$ & $\begin{array}{l}0.327 \\
(0.51)\end{array}$ & $\begin{array}{c}206.85^{*} \\
(1.72)\end{array}$ & $\begin{array}{c}0.326 * * * \\
(4.06)\end{array}$ & $\begin{array}{l}0.293 \\
(0.77)\end{array}$ \\
\hline Introductory period & $\begin{array}{l}277.87 * * * \\
(2.58)\end{array}$ & $\begin{array}{l}-0.0335 \\
(0.76)\end{array}$ & $\begin{array}{l}0.2967 \\
(0.75)\end{array}$ & $\begin{array}{l}513.24 * * * \\
(4.87)\end{array}$ & $\begin{array}{l}0.066 \\
(0.92)\end{array}$ & $\begin{array}{c}0.805 * * \\
(2.05)\end{array}$ \\
\hline $\begin{array}{l}\text { Number of products on } \\
\text { market }\end{array}$ & n.a. & n.a. & n.a. & $\begin{array}{l}106.76^{* * *} \\
(3.29)\end{array}$ & $\begin{array}{c}0.081 * * * \\
(3.93)\end{array}$ & $\begin{array}{l}0.228 \\
(1.60)\end{array}$ \\
\hline $\begin{array}{l}\text { Number of products on } \\
\text { market - squared }\end{array}$ & n.a. & n.a. & n.a. & $\begin{array}{c}-11.54^{* * *} \\
(5.31)\end{array}$ & $\begin{array}{c}-0.009 * * * \\
(6.36)\end{array}$ & $\begin{array}{l}-0.017^{*} \\
(1.96)\end{array}$ \\
\hline Post 1997 & n.a. & n.a. & n.a. & $\begin{array}{l}-29.61 \\
(0.22)\end{array}$ & $\begin{array}{l}-0.013 \\
(0.15)\end{array}$ & $\begin{array}{l}-0.127 \\
(0.38)\end{array}$ \\
\hline Post 1997 * Rx Product & n.a. & n.a. & n.a. & $\begin{array}{c}68.74 \\
(0.46)\end{array}$ & $\begin{array}{l}-0.015 \\
(0.13)\end{array}$ & $\begin{array}{c}-1.818^{* * *} \\
(4.01)\end{array}$ \\
\hline Month effects? & Yes & Yes & Yes & Yes & Yes & Yes \\
\hline Year effects? & Yes & Yes & Yes & No & No & No \\
\hline Product effects? & Yes & Yes & Yes & Yes & Yes & Yes \\
\hline R-squared & 0.256 & 0.343 & 0.415 & 0.170 & 0.241 & 0.285 \\
\hline Mean of dependent var. & 271.32 & 0.251 & 6.365 & 271.32 & 0.251 & 6.365 \\
\hline $\mathrm{N}$ & 998 & 916 & 250 & 998 & 916 & 250 \\
\hline
\end{tabular}




\begin{tabular}{|c|c|c|c|c|c|c|}
\hline & \multicolumn{3}{|c|}{ With Year Effects } & \multicolumn{3}{|c|}{ Parameterized Time Trend } \\
\hline & OLS (\$) & Probit $(\$>0)$ & OLS $(\log \$>0)$ & OLS (\$) & Probit $(\$>0)$ & OLS $(\log \$>0)$ \\
\hline OTC & $\begin{array}{l}2567.84^{* * * *} \\
(10.98)\end{array}$ & $\begin{array}{l}0.750 * * * \\
(5.86)\end{array}$ & $\begin{array}{l}10.748^{* * *} \\
(7.13)\end{array}$ & $\begin{array}{l}4517.76^{* * *} \\
\quad(16.60)\end{array}$ & $\begin{array}{l}0.850 * * * \\
(7.80)\end{array}$ & $\begin{array}{l}4.231 * * * \\
(5.26)\end{array}$ \\
\hline Introductory period & $\begin{array}{c}-560.82^{* *} \\
(2.12)\end{array}$ & $\begin{array}{l}-0.132^{*} \\
(1.97)\end{array}$ & $\begin{array}{l}-1.043 \\
(1.32) \\
\end{array}$ & $\begin{array}{l}-39.13 \\
(0.16) \\
\end{array}$ & $\begin{array}{l}-0.022 \\
(0.26) \\
\end{array}$ & $\begin{array}{l}-0.303 \\
(0.36)\end{array}$ \\
\hline $\begin{array}{l}\text { Number of products on } \\
\text { market }\end{array}$ & n.a. & n.a. & n.a. & $\begin{array}{l}446.42^{* * *} \\
(6.07)\end{array}$ & $\begin{array}{l}0.048^{* *} \\
(2.00)\end{array}$ & $\begin{array}{l}0.089 \\
(0.34)\end{array}$ \\
\hline $\begin{array}{l}\text { Number of products on } \\
\text { market - squared }\end{array}$ & n.a. & n.a. & n.a. & $\begin{array}{c}-40.03^{* * * *} \\
(8.12)\end{array}$ & $\begin{array}{c}-0.006 * * * \\
(3.65)\end{array}$ & $\begin{array}{l}-0.016 \\
(0.99)\end{array}$ \\
\hline Post 1997 & n.a. & n.a. & n.a. & $\begin{array}{c}-2426.32 * * * \\
(8.12)\end{array}$ & $\begin{array}{c}-0.389 * * * \\
(2.94)\end{array}$ & $\begin{array}{l}-0.361 \\
(0.65)\end{array}$ \\
\hline Post 1997 * Rx Product & n.a. & n.a. & n.a. & $\begin{array}{l}3072.16^{* * *} \\
(9.13)\end{array}$ & $\begin{array}{l}0.540 * * * \\
(2.87)\end{array}$ & $\begin{array}{c}3.518^{* * *} \\
(4.26)\end{array}$ \\
\hline Month effects? & Yes & Yes & Yes & Yes & Yes & Yes \\
\hline Year effects? & Yes & Yes & Yes & No & No & No \\
\hline Product effects? & Yes & Yes & Yes & Yes & Yes & Yes \\
\hline R-squared & 0.444 & 0.430 & 0.514 & 0.472 & 0.374 & 0.334 \\
\hline Mean of dependent var. & 925.17 & 0.310 & 6.740 & 925.17 & 0.310 & 6.740 \\
\hline $\mathrm{N}$ & 998 & 916 & 309 & 998 & 916 & 309 \\
\hline
\end{tabular}




\begin{tabular}{|c|c|c|c|c|}
\hline & \multicolumn{2}{|c|}{ Number of Advertisements } & \multicolumn{2}{|c|}{ Pages of Advertisements } \\
\hline & 1 & 2 & 3 & 4 \\
\hline OTC & $\begin{array}{c}0.062 * * * \\
(7.14)\end{array}$ & $\begin{array}{c}0.049 * * * \\
(4.77)\end{array}$ & $\begin{array}{c}0.058^{* * *} \\
(2.92)\end{array}$ & $\begin{array}{l}0.033 \\
(1.43)\end{array}$ \\
\hline OTC * JAMA & $\begin{array}{l}-0.124^{* * *} \\
(5.98)\end{array}$ & $\begin{array}{c}-0.124 * * * \\
(5.96)\end{array}$ & $\begin{array}{c}-0.366^{* * * *} \\
(7.70)\end{array}$ & $\begin{array}{c}-0.366^{* * * *} \\
(7.66)\end{array}$ \\
\hline OTC * NEJM & $\begin{array}{c}-0.131 * * * \\
(6.30)\end{array}$ & $\begin{array}{c}-0.131 * * * \\
(6.27)\end{array}$ & $\begin{array}{c}-0.455 * * * \\
(9.58)\end{array}$ & $\begin{array}{c}-0.456 * * * \\
(9.53)\end{array}$ \\
\hline Introductory period & $\begin{array}{c}0.095^{* * *} \\
(9.95)\end{array}$ & $\begin{array}{c}0.136 * * * \\
(15.49)\end{array}$ & $\begin{array}{c}0.290 * * * \\
(13.31)\end{array}$ & $\begin{array}{c}0.379 * * * \\
(18.77)\end{array}$ \\
\hline $\begin{array}{l}\text { Number of products on } \\
\text { market }\end{array}$ & n.a. & $\begin{array}{c}0.017^{* * *} \\
(6.39)\end{array}$ & n.a. & $\begin{array}{c}0.026^{* * *} \\
(4.23)\end{array}$ \\
\hline $\begin{array}{l}\text { Number of products on } \\
\text { market - squared }\end{array}$ & n.a. & $\begin{array}{c}-0.002^{* * *} \\
(9.69)\end{array}$ & n.a. & $\begin{array}{c}-.003 * * * \\
(6.60)\end{array}$ \\
\hline Post 1997 & n.a. & $\begin{array}{c}-0.019^{*} \\
(1.69)\end{array}$ & n.a. & $\begin{array}{l}-0.008 \\
(0.30)\end{array}$ \\
\hline $\begin{array}{l}\text { Post } 1997 * \\
\text { Rx product }\end{array}$ & n.a. & $\begin{array}{c}0.023^{*} \\
(1.80)\end{array}$ & & $\begin{array}{l}0.033 \\
(1.10)\end{array}$ \\
\hline Month effects? & Yes & Yes & Yes & Yes \\
\hline Year effects? & Yes & No & Yes & No \\
\hline Magazine effects? & Yes & Yes & Yes & Yes \\
\hline Product effects? & Yes & Yes & Yes & Yes \\
\hline R-squared & 0.0727 & 0.0621 & 0.0879 & 0.0625 \\
\hline Mean of dependent var. & \multicolumn{2}{|c|}{0.0427} & \multicolumn{2}{|c|}{0.0809} \\
\hline $\mathrm{N}$ & \multicolumn{4}{|c|}{25,021} \\
\hline
\end{tabular}


Figure 1

A Typical Advertisement for a Prescription

Smoking Cessation Product

(Not available in this draft) 
Figure 2

Advertising expenditures on Smoking Cessation Products and Programs 1986-2002

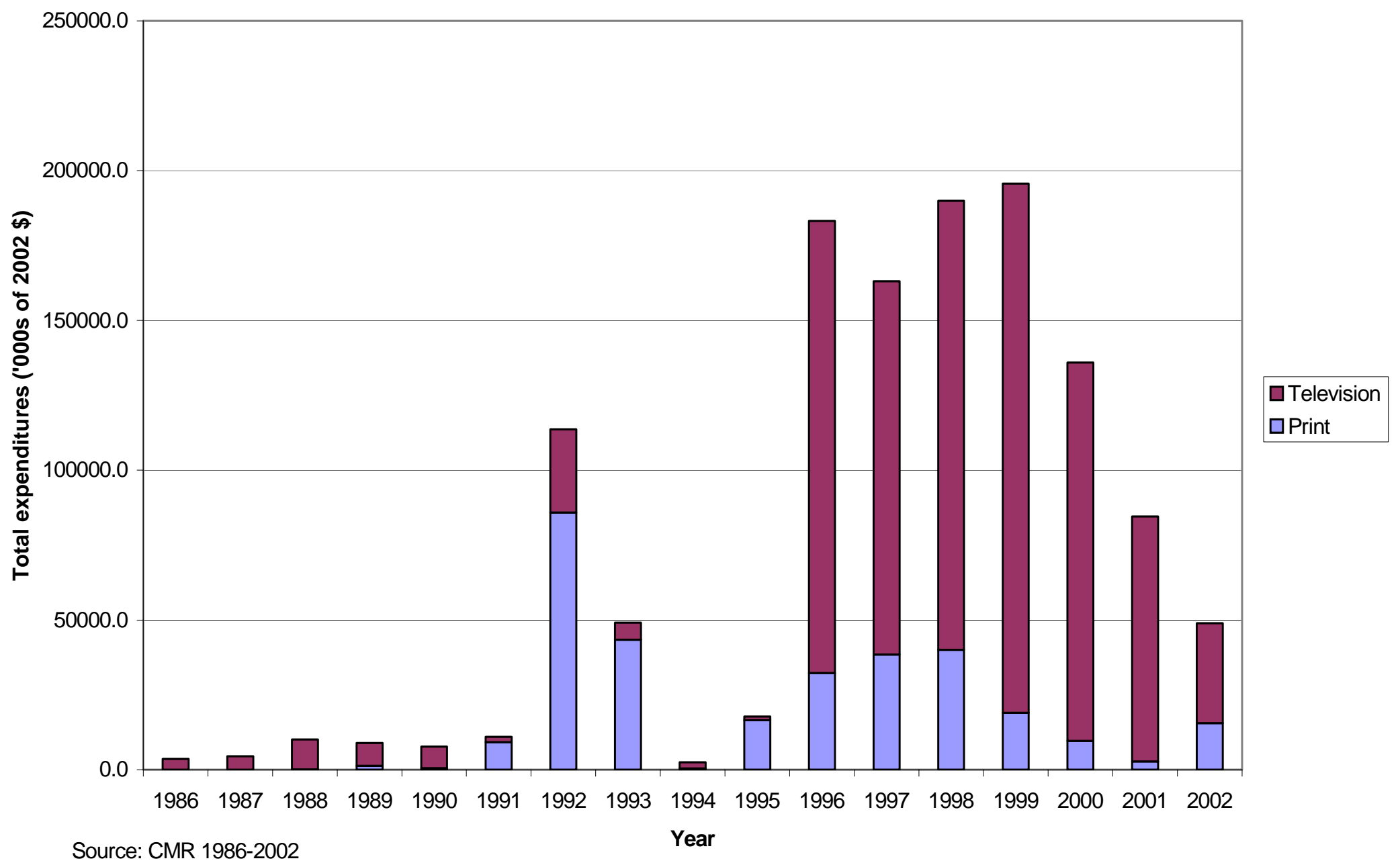


Figure 3

SCADS advertisements versus CMR magazine advertising expenditures

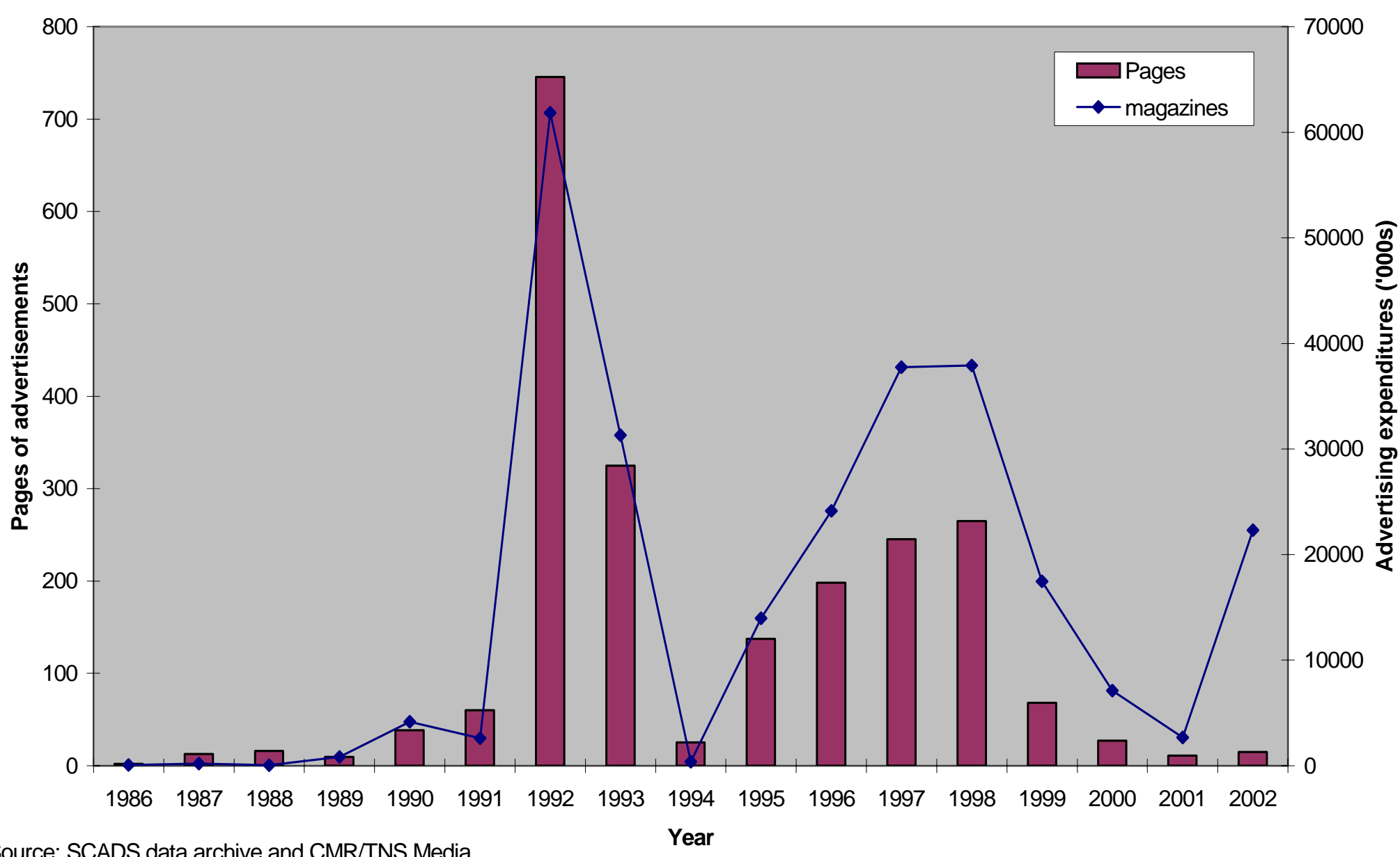

Source: SCADS data archive and CMR/TNS Media 


\section{DATA APPENDIX: The SCADS Archive}

In constructing the sample of magazines in SCADS, we faced a tradeoff between the benefits of wider coverage and the costs of data collection. To select the sample of magazines we used data from the 1998 National Consumer Survey of the Simmons Survey of Media and Markets: Choices II (NCS). These data contain self-reported information on readership of 172 magazines for approximately 20,000 consumers. Using these data, we defined groups based on demographic characteristics (race, education, income, age, gender, smoking status). We then chose the ten magazines most frequently read by members of each group. Because of substantial overlap in the set of magazines most frequently read by different groups, our final sample of magazines includes 26 consumer magazines. In the three cases in which we could not locate copies of all magazines in our sample period (1985-2002) we substituted the magazine that was the next most widely read magazine for the group in question. Based on the NCS data, we calculate that readership of the SCADS sample of 26 magazines accounts for 57.5 percent of the readership of the NCS total sample of 172 magazines. From a source independent of the NCS, we also obtained data on the circulation of 148 of those magazines. The circulation of the 26 magazines in the SCADS sample accounts for 60.7 percent of the total circulation of the 148 magazines. While there are some magazines not included in either the NCS sample or the circulation data, the missing magazines are not widely read; for example, only 0.001 of the NCS respondents read the $172^{\text {nd }}$ ranked magazine in that sample. Thus, two independent calculations suggest that the SCADS sample accounts for almost sixty percent of all U.S. magazines by readership or circulation.

The advertising data archive includes digitally extracted images of all advertisements for smoking products, smoking cessation products, pharmaceutical products, and health-related public service announcements in 28 of the top read magazines in the U.S. for the period January 1985 through May 2002 (17 years and 5 months). Twenty-six of these magazines cover the consumer market and two publications focus primarily on physicians.

Consumer magazines: Ebony, National Geographic, Better Homes \& Gardens, Sports Illustrated, Readers Digest, Time, Money, Modern Maturity, Family Circle, Women's Day, Cosmopolitan, YM, Rolling Stone, Good Housekeeping, Playboy, Glamour, Vibe, Seventeen, Newsweek, Jet, Business Week, TV Guide, People, U.S. News \&World Report, Entertainment Weekly, McCall's/Rosie, Essence.

Physician journals: Journal of the American Medical Association, New England Journal of Medicine.

The archive contains advertisements from approximately 13,497 issues of these magazines. Each advertisement in the data base is coded with the brand name, manufacturer name, length of advertisement, position within the magazine, and for public service announcements, who sponsored the announcement. 
